\title{
Allelopathy Studies in Weed Science in India_A Review
}

\author{
Waseem Mushtaq", Mohammad Badruzzaman Siddiqui \\ Department of Botany, Aligarh Muslim University, Aligarh, India \\ Email address: \\ wsmmushtaq61@gmail.com (W. Mushtaq) \\ ${ }^{*}$ Corresponding author
}

\section{To cite this article:}

Waseem Mushtaq, Mohammad Badruzzaman Siddiqui. Allelopathy Studies in Weed Science in India_-A Review. International Journal of Natural Resource Ecology and Management. Vol. 2, No. 6, 2017, pp. 99-103. doi: 10.11648/j.ijnrem.20170206.11

Received: October 8, 2017; Accepted: October 23, 2017; Published: November 30, 2017

\begin{abstract}
Allelopathy accounts for both beneficiary and detrimental biochemical relations amongst plants. The phenomenon has received great attention since the 1980's all over the world; however, in India, research on allelopathy just started in the late 1980's. Studies have been done with many crops, trees, shrubs and weeds under both laboratory bioassays and field trials to determine their allelopathic potential and its use for weed control. Plants belonging to the Asteraceae family are the most studied species for the allelopathic potential to control weeds. Among the Asteraceae species, allelopathic stress mediated by aqueous extract of differerent parts of Parthenium hysterophorus has been most studied. Allelopathic activity of Ageratum conyzoides has also received deep attention. The individual effect of some allelochemicals has also been investigated. The potential of allelopathy in weed interference on crop production was also studied. In conclusion, allelopathy research should run parallel with contemporary studies such as ecological, horticultural, agricultural, environmental and chemical studies, and an integrated approach ought to be adopted to completely utilize the applicability of allelopathic plant species to addressthe problem of weeds and look for their control.
\end{abstract}

Keywords: Allelopathy, Allelochemicals, Weed Control

\section{Introduction}

The term allelopathy was first coined by Molisch [1] as a means of biological interactions among plants including microorganisms. Rice [2] encompassed such interactions with both detrimental and beneficiary reciprocal biochemical mode of action. The definition was later modified by researchers. Rice in his first approach towards allelopathy used the term for any direct or indirect injurious effect of one plant on another through the discharge of chemical compounds, however, he later came back to Molisch's read [2]. Dakshini et al. [3] cast the term in a wider perspective, such that the other alternative elements of the environment are conjointly affected by the release of allelochemicals from plants as well. They specifically used an advance term 'allelochemical interaction' that includes (1) allelopathy, (2) role of allelochemicals discharged from plants in modifying abiotic (inorganic and organic components) and biotic components of soils, and (3) regulation of the assembly and supreme unleash of allelochemicals by abiotic and biotic factors of the ecosystem. Allelopathy nonetheless is a modern subject, the antiquity of allelopathy is addressed as early as 300 B. C. [2]. However, advanced allelopathic study increased fairly after 1980 [3]. Primarily, allelopathic research was based on bioassays only (e. g., aqueous leachate or extract bioassays in petridishes), although there was some promising worthful ecological work on allelopathy earlier to 1970. Since 1990's, allelopathic analysis reached new heights, shifted from simple laboratory work to an associate integration of field studies [3].

Agriculture holds its reputation both on economic inclusive growth as well as on socially equitable development in India because nearly $70 \%$ of India's population survives in rural areas and is employed in the agricultural sector [4]. India stands 2nd largest producer of agriculture product and accounts for $7.68 \%$ of the total global agricultural output [5]. Agriculture held $17.9 \%$ of Indian GDP composition in 2014 [5]. The contribution of agriculture sector in the Indian economy is much higher than world's average (6.1\%) [5]. India has 1,799,000 $\mathrm{km}^{2}$ 
agricultural land which is over $54.7 \%$ of its total area [6]. S With the advancement in irrigation potentials and various climatic zones, India has many diverse crop patterns, from winter cereals such as rye, barley and wheat to tropical crops like rice and sub-tropical ones such as tea and banana.

Despite tremendous success achieved by Integrated Pest Management (IPM) and its rapid dissemination of information through 26 Central Integrated Pest Management Centers (CIPMCs) located in 23 States and Union Territories of India, pesticide use has amplified. She ranks $12^{\text {th }}$ largest user of pesticides in the world and largest pesticide manufacturer in Asia at present [7]. Although various IPM projects have been employed over the past decade, India's share of pesticide use is $76 \%$ as compared to the world average of $44 \%$ [8]. Nevertheless, IPM farms have proved to be resourceful and more prolific and lucrative than non-IPM farms [9].

Increasing issues associated with weed management, like chemical-resistant weeds and chemical residues of herbicides, broaden the mandate for organic crops, and growing public issues on environmental problems need various farming systems that are less chemical dependent and support natural compounds $[10,11]$. Allelopathy is the potential system that may be used as an alternate methodology to incur weeds in crops $[12,13]$. An exceptional variety of research on allelopathy is conducted in India; however, activities associated with allelopathy don't seem to be well documented within the international scientific community.

There is not much survey that specifically reports allelopathic activities in India. Therefore, the purpose of this paper is to review allelopathy studies associated with weed science in India and to address current and future prospects. Additionally, some major problems regarding Indian agriculture and its explicit weed issues are mentioned.

\section{The Popular Allelopathic Weeds of India}

\subsection{Lantana Camera L.}

Lantana camera L. (Verbenaceae family) is one of the world's top 10 worst weeds has become a major problem in many states of India since its introduction in the country at the beginning of $19^{\text {th }}$ century. The wild sage (Lantana camera L.) is an obnoxious weed and poses a serious threat to local vegetation through its allelopathic action [14]. The allelochemicals present are phenolics, with umbelliferone, methylcoumarin, and salicylic acid being the utmost phytotoxic [14]. In addition to phenolics, a recent report indicates lantadene $\mathrm{A}$ and $\mathrm{B}$ as more intoxicating allelochemicals present in Lantana [14]. Lantana is one of the most problematic weeds and the plant has evolved not only in plains of India but also in Himalayan regions [15].

Many studies in India have reported the allelopathic effect of Lantana on germination and growth of native vegetation
$[16,17,18,19,20,21]$.

\subsection{Parthenium Hysterophorus L.}

Parthenium hysterophorus L. (Asteraceae family, unremarkably referred to as congress grass) is thought to have entered India between the 1950s and 1960s in conjunction with foreign food imported from the USA [22]. It was initially noticed in 1955 on the fringes of Pune (Maharashtra) and delineated taxonomically in 1956 by Rao [22]. P. hysterophorus is probably the foremost difficult and vesicant weed of urban and rural India with extensive growth on hilly scraps. Besides quick colonization along with the ability to exchange the native vegetation, it's additionally best-known to cause a variety of human health issues like skin allergic reactions, mild fever and irritation to eyes of the residents within the section [23]. Similarly, it leads to fodder deficiency moreover to being unappetizing and toxic to farm animals. The allelopathic tendency of $P$. hysterophorus has been well framed and phytochemical extraction of soluble phenolics and sesquiterpene lactones has been testified from the roots, stems, leaves, inflorescences, spore and seeds [23]. Rajan [24] and Kanchan [25] were the first to detect the occurrence of plant growth suppressors in the weed, and therefore the latter author recognized parthenin, caffeic acid and p-coumaric acid as the chief inhibitors found in its stem.

Allelopathic effects have been reported with the foliar leachates of Parthenium hysterophorus on a varied range of agronomic and tree crops: Vigna unguiculata, Helianthus, Casuarina, Acacia, Eucalyptus and Leucaena [26]; Oryza sativa, Triticum, Vigna mungo and Cicer arietinum [27]; Vigna radiata and Triticum [28]; Hordeum vulgare and Cassia tora [29]; Vigna radiata and Cyamopsis tetragonoloba [30]; various species of Indian forage crops, pulses and oilseeds [31].

\subsection{Ageratum Conyzoides L.}

Ageratum conyzoides (Asteraceae family; commonly known as billy goat weed, bill goat weed, goat weed or tropical white weed) has annexed agricultural fields. It interferes with crops and causes a loss in yield of main indispensable crops of India [22, 32, 33], including the northwest Himalayas, eastern Himalayas, central India and Western Ghats. Once it invades land areas, it thwarts native grasses inflicting insufficiency of fodder. It is a weed of arable land found largely in cultivated areas, grasslands and pastures intrusive to the growth and development of crops, grasses and forage crops. It is a stern encroacher of the medicinally and aromatically essential plants tempting on the floor under the canopy of forest cover and critically threatens to be deadly for the profusion and assortment of these herbal plants. This weed was known to persist in India prior to 1882 as described in "The Flora of British India" [34]. Furthermore, perhaps it was hosted as an ornamental plant, however, later it absconded and attained a weedy habit, although no authentic report is obtainable in this regard.

Ageratum has been reported to negatively affect the 
growth and yield of crops and various other native species by discharging a variety of phenolic compounds and volatile oils from its foliage $[35,36]$. The exact figures concerning the percent loss of yield are not framed, nonetheless, it is determined by the intensity capacity of weed. Roder et al. (1998) have reported that yield of rice is negatively associated with the density of Ageratum [37]. Ageratum due to its heavy infestation intensity ruined the croplands of farmers of the lower Shivalik ranges of the Himalayas due to which farmers even abandoned their fields. The strong and pungent smell of this weed can also cause giddiness, nausea and allergic reactions in humans as well.

\subsection{Croton Bonplandianum Baill}

Croton bonplandianum is a loathsome aggressive weed of Euphorbiaceae family. It is native to South America and is reported in India since the late 1890s [38]. It presently happens extensively along roadsides, railway tracks, unrestrained fields in wide exposed ravines and rice or sugarcane fields and on grimy or sandy clay soils. This species is rarely established in areas bounded by shrubs and trees wherever free movement of air sets stalled. For noticeable reasons, $C$. bonplandianum is a challenging weed for farmers, agriculturalists, ecologists/biologists, horticulturists, environmentalists and the common man, particularly in North India. It is in constant competition with other plant species leading to adverse effects on the pattern of natural vegetation and economically important crops. Moreover, its invasion in crop fields hampers the agricultural preparations.

The aqueous extracts of Croton from its different parts showed significant inhibition on sapling growth of crop plants (Triticum aestivum L., Brassica oleracea var. botrytis L. and Brassica rapa L.) and weed plants (Melilotus alba Medik., Vicia sativa L. and Medicago hispida Gaertn) [39]. This weed displayed its allelopathic affect even on mature growth phases of wheat and mustard [40]; and another intrusive weed, Parthenium hysterophorus as well [41].

\section{Recent Allelopathic Studies in India}

Realizing the increasing scope of allelopathy, eminent researchers of India have also focussed on modern research to grow in this subject. Raoof and Siddiqui (2012) evaluated the inhibitory effect of aqueous extract of Tinospora cordifolia (Willd.) on germination and growth of weed plants (Chenopodium album L. Chenopodium murale L., Cassia tora L. and Cassia sophera L.) [42]. Gulzar and Siddiqui (2014) studied the allelopathic stress produced by Eclipta alba weed on seed germination and sapling growth of weeds (Cassia tora L., Cassia sophera L.) and crops (Phaseolus aureus L., Oryza sativa L.) [43]; the same authors (2013) had also evaluated the allelopathic impact of Terminalia arjuna (Roxb.) wight and arn bark against Cassia sophera [44]. Gulzar et al. (2014) studied the allelopathic and elemental investigation of Eclipta alba (L.) Hassk. and determined allelopathic capacity of its rhizosphere amended soil on growth of crop plants and weed species [45]. A more recent investigation was undertaken by Chopra et al. (2017) to study the allelopathic effect of Echinochloa colona L. and Cyperus iria L. on the seedling germination and primary growth of rice and soyabean [46].

\section{Competing Interests}

The authors declare no conflict of interests regarding the publication of the paper.

\section{Acknowledgements}

This work was carried under the UGC Fellowship, Government of India. The financial assistance of the UGC, India is gratefully acknowledged.

\section{References}

[1] Molisch, H. (1937). Einfluss einer pflanze auf die andere, Allelopathie.

[2] Rice, E. L. (1984). Allelopathy, 2nd ed., academic press, New York.

[3] Dakshini, K. M. M., \& Foy, C. L. (1999). Allelopathy: One component in a multifaceted approach to ecology. In Principles and Practices in Plant Ecology: Allelochemical Interactions (pp. 3-14). CRC Press LLC.

[4] http://www.business-standard.com/article/economy-policy/70indians-live-in-rural-areas-census-111071500171_1.html.

[5] http://statisticstimes.com/economy/sectorwise-gdpcontribution-of-india.php.

[6] http://en.worldstat.info/Asia/India/Land\%2003.10.2017.

[7] Abhilash, P. C., \& Singh, N. (2009). Pesticide use and application: an Indian scenario. Journal of hazardous materials, 165, 1-12.

[8] http://www.thehindu.com/news/cities/Coimbatore/pesticideuse-in-indian-agriculture-is-less-than-worldaverage/article4364739.ece。

[9] Krishna, V. V., Byju, N. G., \& Tamizheniyan, S. (2000). Integrated pest management in Indian agriculture: a developing economy perspective. Integrated Pest Management, 1999, 1998.

[10] Singh, H. P., Batish, D. R., \& Kohli, R. K. (2003). Allelopathic interactions and allelochemicals: new possibilities for sustainable weed management. Critical reviews in plant sciences, 22 (3-4), 239-311.

[11] Waller, G. R. (2004). Introduction-reality and future of allelopathy. Allelopathy: Chemistry and Mode of Action of Allelochemicals (eds. Macias FA, Galindo JCG, Molinilla $H M G$, Cutler $H G), 1-12$.

[12] Rice, E. L. (1995). Biological control of weeds and plant diseases: advances in applied allelopathy. University of Oklahoma Press. 
[13] Keating, K. I. (1999). Allelopathy: principles, procedures, processes, and promises for biological control. Advances in Agronomy, 67, 141-231.

[14] Sharma, O. P., Sharma, S., Pattabhi, V., Mahato, S. B., \& Sharma, P. D. (2007). A review of the hepatotoxic plant Lantana camara. Critical reviews in toxicology, 37 (4), 313352.

[15] Kohli, R. K., Dogra, K. S., Batish, D. R., \& Singh, H. P. (2004). Impact of invasive plants on the structure and composition of natural vegetation of northwestern Indian Himalayas. Weed Technology, 18 (sp 1), 1296-1300.

[16] Bansal, G. L. (1998). Allelopathic effect of Lantana camara on rice and associated weeds under the midhill conditions of Himachal Pradesh, India. In proceedings of the workshop on allelopathy in Rice. Manila (Philippines): International Rice Research Institute (pp. 133-138).

[17] Oudhia, P., \& Tripathi, R. S. (2000). Allelopathic effect of Lantana camara L. on germination of kodo (Paspalum scrobiculatum L.). Agricultural Science Digest, 20 (4), 263264.

[18] Nawab, N. P., \& Yogamoorthi, A. (2016). Allelopathic effects of aqueous extract of Lantana camara L. on seed Germination of black gram Vigna mungo L. Environmental Science: An Indian Journal, 12 (11).

[19] Shrivastava, S., \& Jha, A. K. (2016). Effect of leaf extract of Lantana camara on growth of seedlings of Cicer arietinum.

[20] Gantayet, P. K., Adhikary, S. P., Lenka, K. C., \& Padhy, B. (2014). Allelopathic impact of Lantana camara on vegetative growth and yield components of green gram (Phaseolus radiatus). International Journal of Current Microbiology and Applied Sciences, 3 (7), 327-335.

[21] Pankaj, U., Shikha, B., \& Bharat, V. (2011). Allelopathic potential of aqueous extracts of Lantana camara with Raphanus sativus. International Journal of Agriculture Environment \& Biotechnology, 4 (4), 351-355.

[22] Kohli, R. K., Batish, D. R., Singh, H. P., \& Dogra, K. S. (2006). Status, invasiveness and environmental threats of three tropical American invasive weeds (Parthenium hysterophorus L., Ageratum conyzoides L., Lantana camara L.) in India. Biological Invasions, 8 (7), 1501-1510.

[23] Evans, H. C. (1997). Parthenium hysterophorus. A review of its weed status and the possibilities for biological control. Biocontrol News and Information, 18, 89N-98N.

[24] Rajan, L. (1973). Growth inhibitor (S) from Parthenium Hysterophorus Linn. Current Science.

[25] Kanchan, S. D. (1975) Growth inhibitors from Parthenium hysterophorus Linn. Current Science 44, 358-359.

[26] Swaminathan, C., Rai, R. V., \& Suresh, K. K. (1990). Allelopathic effects of Parthenium hystero-phorus on germination and seedling growth of a few multi-purpose trees and arable crops. International Tree Crops Journal, 6 (2-3), 143-150.

[27] Singh, S. P. (1991). Allelopathic potential of Parthenium hysterophorus L. Journal of Agronomy and Crop Science, 167 (3), 201-206.

[28] Agarwal, C., \& Anand, A. (1992, February). Ecological
Studies on allelopathic potential of Parthenium hysterophorus L. in relation to Phaseolus aureus L. and Triticum aestivum L. Narwal, SS. In Proceeding of the 1st National Symposium on Alleopathy in Agroecosystems, Hisar, India (pp. 61-65).

[29] Singh, K., Shahi, A. K., Pal, S., \& Balyan, S. S. (1992, February). Phyto-allelopathic influence of Parthenium hysterophorus L. In Proceedings of first national symposium on allelopathy in agroecosystems (agriculture and forestry), Indian Society of Allelopathy, Hisar, India (pp. 61-63).

[30] Kohli, R. K., \& Rani, D. (1992, February). Identification and bioefficacy of soil chemics of Parthenium. In Proccedings of the 1st National Symposium on Allelopathy in agroecosystems, Hisar, India, Februaray (pp. 196-198).

[31] Aggarwal, A., \& Kohli, R. K. (1992, February). Screening of crops for seed germination against Parthenium hysterophorus L. Leachates. In Proceedings of the 1st national symposium on allelopathy in agroecosystems, Hisar, India (pp. 66-68).

[32] Yoganarasimhan, S. N. (2000). Medicinal plants of India. Volume 2. Tamil Nadu. Bangalore: The Author $i$.

[33] Silori, C. S., \& Mishra, B. K. (2001). Assessment of livestock grazing pressure in and around the elephant corridors in Mudumalai Wildlife Sanctuary, south India. Biodiversity \& Conservation, 10 (12), 2181-2195.

[34] Stearn, W. T. (1965). Grisebach's flora of the British west Indian islands: a biographical and bibliographical introduction. Journal of the Arnold Arboretum, 46 (3), 243-285.

[35] Kong, C., Hu, F., Xu, T., \& Lu, Y. (1999). Allelopathic potential and chemical constituents of volatile oil from Ageratum conyzoides. Journal of Chemical Ecology, 25 (10), 2347-2356.

[36] Singh, H. P., Batish, D. R., Pandher, J. K., \& Kohli, R. K. (2003). Assessment of allelopathic properties of Parthenium hysterophorus residues. Agriculture, ecosystems \& environment, 95 (2), 537-541.

[37] Roder, W., Keoboulapha, B., Phengchanh, S., Prot, J. C., \& Matias, D. (1998). Effect of residue management and fallow length on weeds and rice yield. Weed Research, 38, 167-174.

[38] Kaul, V. (1967). Distibution and dispersal of Croton sparsiflorus Morong. J. Ind. Bot. Soc, 46, 154-159.

[39] Sisodia, S., \& Siddiqui, M. B. (2010). Allelopathic effect by aqueous extracts of different parts of Croton bonplandianum Baill. on some crop and weed plants. Journal of Agricultural Extension and Rural Development, 2 (1), 022-028.

[40] Sarkar, E., \& Chakraborty, P. (2010). Allelopathic effect of Croton bonplandianum Baill. on mature growth phases of Wheat and Mustard. The IUP Journal of Life Sciences, 4, 2532 .

[41] Singh, N. B., \& Thapar, R. (2002). Allelopathic effects of Croton bonplandianum on Parthenium hysterophorus. Allelopathy Journal, 10 (2), 163-170.

[42] Raoof, K. A., \& Siddiqui, M. B. (2012). Evaluation of allelopathic impact of aqueous extract of root and aerial root of Tinospora cordifolia (Willd.) Miers on some weed plants. Analele Universităţii din Oradea-Fascicula Biologie, 1, 2934. 
[43] Gulzar, A., \& Siddiqui, M. B. (2014). Allelopathic effect of aqueous extracts of different part of Eclipta alba (L.) Hassk. on some crop and weed plants. Journal of agricultural extension and rural development, 6 (1), 55-60.

[44] Gulzar, A., \& Siddiqui, M. B. (2013). Evaluation for allelopathic impact of Terminalia arjuna (Roxb.) wight and arn bark against Cassia sophera. African Journal of Agricultural Research, 8 (39), 4937-4940.

[45] Gulzar, A., Siddiqui, M. B., \& Bi, S. (2014). Allelopathic potential of rhizosphere powder amended soil (LPRS) and inorganic profiling of Eclipta alba (L.) Hassk. on growth of crops and weeds. Thai Journal of Agricultural Science, 47 (3), 133-139.

[46] Chopra, N., Tewari, G., Tewari, L. M., Upreti, B., \& Pandey, N. (2017). Allelopathic Effect of Echinochloa colona L. and Cyperusiria L. Weed Extracts on the Seed Germination and Seedling Growth of Rice and Soyabean. Advances in Agriculture, 2017. 